\title{
Corticosteroids in severe community-acquired pneumonia: the path we choose depends on where we want to get
}

\author{
Jorge IF Salluh*1,2, Márcio Soares ${ }^{1,2}$ and Pedro Póvoa ${ }^{3}$ \\ See related research by Fernández-Serrano et al., http://ccforum.com/content/15/2/R96
}

\begin{abstract}
Severe community-acquired pneumonia is a major cause of admission to intensive care units and its mortality rates remain exceedingly high. In the search for adjunctive therapies, clinicians who were encouraged by available, though limited, evidence prescribed steroids in most patients with severe sepsis or septic shock, including those with communityacquired pneumonia. Current evidence demonstrates that, whereas corticosteroids should not be routinely employed as adjuvant therapy for severe communityacquired pneumonia, there is sufficient equipoise to continue studying the use of corticosteroids.
\end{abstract}

In this issue of Critical Care, Fernández-Serrano and colleagues [1] evaluate the efficacy of corticosteroids in the treatment of hospitalized patients with severe community-acquired pneumonia (CAP). Severe CAP is a major cause of admission to intensive care units (ICUs) and, despite optimal antibiotic and supportive treatment, remains associated with exceedingly high mortality rates [2]. For this legitimate reason, intensivists have worked for decades in numerous clinical trials aiming to identify adjunctive strategies for this condition. In this sense, corticosteroids are the prototypical 'ideal candidate'. Corticosteroids present anti-inflammatory properties that may reduce the intense proinflammatory cytokine response and thus modify the occurrence and severity of organ failures [3]. Also, corticosteroids are easily administrated and relatively inexpensive and, clinicians

*Correspondence: jorgesalluh@gmail.com

'D'Or Institute for Research and Education, Rua Diniz Cordeiro, 30, Botafogo,

Rio de Janeiro, 22281-100, Brazil

Full list of author information is available at the end of the article believe, do no harm. Given this long list of favorable attributes and the positive results from a multicenter randomized controlled trial (RCT) [4], it is fair of us physicians to want corticosteroids to fill the role of 'the ideal adjunctive sepsis therapy'.

In 1958, the Canadian-American economist John Kenneth Galbraith coined the expression 'conventional wisdom. The term was employed to describe concepts that are generally accepted as true without being questioned. Although such ideas are widely held, further examination based on solid evidence proves them to be wrong. This may apply to what happened to corticosteroids in sepsis in the last decade.

Physicians encouraged by available evidence and conventional wisdom prescribed steroids in up to $80 \%$ of patients with severe sepsis and septic shock [5]. The reliance on corticosteroids as the best choice was so strong that it reduced the patient inclusion rate in the Corticus Study and potentially made the study biased for including only patients who, their physicians believed, would not require steroids [6]. The willingness to prescribe corticosteroids is disproportionately elevated given the available evidence.

In patients with severe sepsis, clinical trials [6], welldesigned observational studies [7], and data from an international registry [5] could not demonstrate a reduced need for vasopressors or an improvement in organ dysfunctions or survival. In regard to severe CAP, a systematic review performed in 2008 had already pointed out that the available studies do not support the recommendation of corticosteroids as a standard of care [8]. Subsequent observational data [9] and an RCT [10] also failed to show any significant clinical benefit associated with corticosteroid administration for this subgroup of patients, irrespective of disease severity.

Fernández-Serrano and colleagues [1] present the results of a small $(\mathrm{n}=45)$ single-center RCT evaluating the potential benefit of a methylprednisolone (MPRD) regimen on outcomes of non-ICU CAP patients, namely 
the need for invasive or non-invasive mechanical ventilation. MPRD was found to be associated with a faster clinical, radiological, and laboratory resolution of CAP, but with similar mortality. The issue of small sample size notwithstanding, five patients (22.7\%) from the placebo group needed ICU admission and three required invasive mechanical ventilation, whereas only one from the MPRD arm was admitted to the ICU for non-invasive ventilation, and this resulted in a marked asymmetry between the two groups. Despite these caveats, the authors were able to conclude that MPRD had a positive impact on the clinical course of these very select CAP patients. In our opinion, the results are hard to translate into daily practice because of patient selection and small sample size and should be viewed with a measure of caution.

In view of the current evidence, what is the future of corticosteroids in severe CAP? Is there clinical equipoise to justify new clinical trials in this topic? Given the current studies, it can be said that, although there is insufficient evidence to support corticosteroid use as the standard of care in severe CAP, it is still an unresolved matter that deserves further investigation. Future trials should learn from previously published studies to overcome their limitations. This does not mean that we should repeat previous studies with larger sample sizes. Instead, we must work on better study designs that make use of a reliable surrogate of outcomes and that represent a true advance in the refinement of patient selection. Unlike in the examples of severe sepsis and CAP, better patient selection may lead to significant clinical benefits for subgroups of patients with severe infections treated with adjunctive corticosteroids. Benefits of systemic corticosteroids in septic patients were demonstrated only in well-defined infections such as bacterial meningitis in immunocompetent hosts [11] and Pneumocystis jirovecci pneumonia in HIV patients [12]. Nonetheless, despite new scoring systems [13] and biomarkers, these tools are not validated as surrogates of response to corticosteroids [14].

In conclusion, we believe that, while corticosteroids should not be routinely employed as adjuvant therapy for severe CAP, there is sufficient equipoise to continue studying the use of corticosteroids. This is still an open field that may significantly evolve by applying the concept of theragnostics for severe CAP.

\section{Abbreviations}

CAP, community-acquired pneumonia; ICU, intensive care unit; MPRD, methylprednisolone; $\mathrm{RCT}$, randomized controlled trial.

\section{Competing interests}

The authors declare that they have no competing interests.

\section{Author details}

'D'Or Institute for Research and Education, Rua Diniz Cordeiro, 30, Botafogo, Rio de Janeiro, 22281-100, Brazil. 2Postgraduation Program, Instituto Nacional de Câncer, Praça Cruz Vermelha - Centro, Rio de Janeiro, 20230-130, Brazil. ${ }^{3}$ Polyvalent Intensive Care Unit, Unidade de Cuidados Intensivos Polivalente, Hospital São Francisco Xavier, Centro Hospitalar de Lisboa Ocidental, EPE, Estrada do Forte do Alto do Duque, 1449-005 Lisboa, Portugal.

Published: 24 March 2011

\section{References}

1. Fernández-Serrano S, Dorca J, Garcia-Vidal C, Fernández-Sabé N, Carratalà J, Fernández-Aguera A, Corominas M, Padrones S, Gudiol F, Manresa F: Effect of corticosteroids on the clinical course of community-acquired pneumonia: a randomized controlled trial. Crit Care 2011, 15:R96.

2. Vincent JL, Rello J, Marshall J, Silva E, Anzueto A, Martin CD, Moreno R, Lipman J, Gomersall C, Sakr Y, Reinhart K; EPIC II Group of Investigators: International study of the prevalence and outcomes of infection in intensive care units. JAMA 2009, 302:2323-2329.

3. Annane $D$, Cavaillon JM: Corticosteroids in sepsis: from bench to bedside? Shock 2003, 20:197-207.

4. Annane D, Sébille V, Charpentier C, Bollaert PE, François B, Korach JM, Capellier G, Cohen Y, Azoulay E, Troché G, Chaumet-Riffaud P, Bellissant E: Effect of treatment with low doses of hydrocortisone and fludrocortisone on mortality in patients with septic shock. JAMA 2002, 288:862-871.

5. Beale R, Janes JM, Brunkhorst FM, Dobb G, Levy MM, Martin GS, Ramsay G, Silva E, Sprung CL, Vallet B, Vincent JL, Costigan TM, Leishman AG, Williams $M D$, Reinhart K: Global utilization of low-dose corticosteroids in severe sepsis and septic shock: a report from the PROGRESS registry. Crit Care 2010, 14:R102.

6. Sprung CL, Annane D, Keh D, Moreno R, Singer M, Freivogel K, Weiss YG, Benbenishty J, Kalenka A, Forst H, Laterre PF, Reinhart K, Cuthbertson BH Payen D, Briegel J; CORTICUS Study Group: Hydrocortisone therapy for patients with septic shock. N Engl J Med 2008, 358:111-124.

7. Ferrer R, Artigas A, Suarez D, Palencia E, Levy MM, Arenzana A, Perez XL, Sirvent JM: Effectiveness of treatments for severe sepsis: a prospective, multicenter, observational study. Am J Respir Crit Care Med 2009, 180:861-866.

8. Salluh Jl, Povoa P, Soares M, Castro-Faria-Neto HC, Bozza FA, Bozza PT: The role of corticosteroids in severe community-acquired pneumonia: a systematic review. Crit Care 2008, 12:R76.

9. Salluh JI, Soares M, Coelho LM, Bozza FA, Verdeal JC, Castro-Faria-Neto HC, Silva JR, Bozza PT, Povoa P: Impact of systemic corticosteroids on the clinical course and outcomes of patients with severe community-acquired pneumonia: a cohort study. J Crit Care 2010 Oct 1. [Epub ahead of print].

10. Snijders D, Daniels JM, de Graaff CS, van der WerfTS, Boersma WG: Efficacy of corticosteroids in community-acquired pneumonia: a randomized double-blinded clinical trial. Am J Respir Crit Care Med 2010, 181:975-982.

11. van de Beek D, de Gans J, McIntyre P, Prasad K: Corticosteroids for acute bacterial meningitis. Cochrane Database Syst Rev 2007 (1):CD004405.

12. Briel M, Bucher HC, Boscacci R, Furrer H: Adjunctive corticosteroids for Pneumocystis jiroveci pneumonia in patients with HIV-infection. Cochrane Database Syst Rev 2006, 3:CD006150.

13. Rello J, Rodriguez A, Lisboa T, Gallego M, Lujan M, Wunderink R: PIRO score for community-acquired pneumonia: a new prediction rule for assessment of severity in intensive care unit patients with communityacquired pneumonia. Crit Care Med 2009, 37:456-462.

14. Salluh JI, Shinotsuka CR, Soares M, Bozza FA, Lapa e Silva JR, Tura BR, Bozza PT, Vidal CG: Cortisol levels and adrenal response in severe communityacquired pneumonia: a systematic review of the literature. J Crit Care 2010, 25:541.e1-8.

doi:10.1186/cc10099

Cite this article as: Salluh JIF, et al.: Corticosteroids in severe communityacquired pneumonia: the path we choose depends on where we want to get. Critical Care 2011, 15:137. 